\title{
Status Kualitas Air di Kolam Bekas Tambang Batubara di Tambang Satui, Kabupaten Tanah Laut, Kalimantan Selatan
}

\section{Status of Water Quality in Void Ponds of Coal Mining in Tambang Satui, Tanah Laut District, South Borneo}

\author{
NUSA IDAMAN SAID DAN SATMOKO YUDO \\ Pusat Teknologi Lingkungan, Badan Pengkajian dan Penerapan Teknologi \\ Gedung Geostech 820 Lt.3, Kawasan Puspiptek, Tangerang Selatan, 15314 \\ Email : nusa.idamansaid@bppt.go.id dan satmoko.yudo@bppt.go.id
}

\begin{abstract}
Coal mining can have positive and negative impacts on the environment. The positive effects include providing new employment opportunities and increasing regional income as well as foreign exchange. In comparison, negative consequences could be the changes in the environment's quality and sustainability, caused by the formation of ex-mining pits and acid mine drainage, which reduce the quality of surrounding soil and water. This study aimed to determine the water quality of the ex-mining ponds at the Antasena Pit, Satui Mine, Kintap District, Tanah Laut Regency, South Kalimantan. This research measured the ponds' water quality directly on site. Meanwhile, the water samples were taken and analyzed in the laboratory. The laboratory analyzes showed that, in general, the physicochemical and biological parameters were under Class 1 Water Quality Standards of the Government Regulation Number 82 the Year 2001 on Water Quality Management and Water Pollution Control.
\end{abstract}

Keywords : coal mining, ex-mining ponds, pond water quality

\begin{abstract}
ABSTRAK
Penambangan batubara dapat memberikan dampak positif dan negatif terhadap lingkungan. Dampak positif tersebut antara lain membuka lapangan kerja baru dan meningkatkan pendapatan daerah serta devisa negara. Sedangkan dampak negatifnya adalah terjadinya perubahan kualitas dan kelestarian lingkungan akibat terbentuknya lubang bekas tambang dan timbulnya air asam tambang yang menurunkan kualitas tanah dan air di sekitarnya. Tujuan penelitian ini adalah untuk mengetahui kualitas air kolam bekas penambangan di Pit Antasena, Tambang Satui, Kecamatan Kintap, Kabupaten Tanah Laut, Kalimantan Selatan. Kualitas air kolam diukur langsung di lokasi dan sampel air diambil dan dianalisis di laboratorium. Analisis laboratorium menunjukkan bahwa secara umum parameter fisikakimiawi dan biologi telah sesuai dengan Standar Kualitas Air Kelas 1 sesuai Peraturan Pemerintah RI Nomor 82 Tahun 2001 tentang Pengelolaan Kualitas Air dan Pengendalian Pencemaran Air.
\end{abstract}

Kata kunci : tambang batu bara, kolam bekas tambang, kualitas air kolam.

\section{PENDAHULUAN}

\subsection{Latar Belakang}

$\begin{array}{llr}\text { Sebagian besar } & (71,21 \%) & \text { konsumsi } \\ \text { batubara domestik } & \text { digunakan } & \text { sebagai }\end{array}$ pembangkit listrik (PLTU), kemudian digunakan industri semen (14,24\%), industri tekstil $(7,15 \%)$, industri kertas $(5,28 \%$, pengecoran logam $(0,70 \%)$, dan industri lainnya $(1,42 \%)^{(1)}$. Hal tersebut menunjukkan peran batubara dalam industri cukup penting.

Perusahaan-perusahaan penambangan batu-bara pada umumnya sering menerapkan sistem open cut mining atau tambang terbuka ${ }^{(2)}$. Permasalahan yang ada pada sistem penambangan secara terbuka ini biasanya setelah selesai dilakukan metode backfilling atau penimbunan kembali pasca tambang, akan tetapi hal tersebut tidak dilakukan sehingga meninggalkan lubang-lubang bekas tambang ${ }^{(3)}$. Lubang bekas tambang atau disebut juga void yang ditinggalkan pada pasca tambang tanpa adanya perencanaan pemanfaatan yang baik, akan berpotensi menimbulkan dampak yang buruk bagi lingkungan.

Selain itu dampak lainnya adalah timbulnya air asam tambang. Air asam tambang terbentuk karena dipengaruhi oleh 3 (tiga) faktor utama yaitu material yang mengandung mineralmineral sulfida dan air serta udara ${ }^{(4)}$. Faktorfaktor yang berpotensi membentuk air asam tambang adalah akibat sistem tambang yang terbuka yang berhubungan langsung dengan udara bebas sehingga semakin mudah bereaksi ${ }^{(5)}$. 
Salah satu void sisa bukaan akhir tambang di Kecamatan Kintap, Kabupaten Tanah laut adalah Void Pit Antasena yang telah selesai ditambang (mined out) pada tahun 2010. Void ini terbagi dua void yaitu void Antasena Timur dengan luas 46,7 ha dan void Antasena Barat dengan luas 28,7 ha. Void-void ini telah digenangi air dan menjadi kolam besar yang membentuk seperti danau.

Dalam rangka melengkapi dan mendetilkan rancangan pengelolaan dan pemanfaatan kolam tersebut hingga penutupan tambang, maka diperlu-kan kajian yang mencakup karakteristik kolam yang mendasari perencanaan desain akhir pemanfaatan kolam tersebut, disertai alternatif-alternatif pemanfaatannya yang dinilai optimal. Salah satu rencana pemanfaatan kolam void Antasena adalah untuk sumber air atau budidaya perikanan.

Hal ini sesuai dengan Peraturan Menteri ESDM Nomor 7 Tahun 2014(6) disebutkan bahwa program reklamasi dapat dilaksanakan untuk keperluan lainnya seperti sumber air, budidaya perikanan, irigasi, dan wisata.

Berkaitan dengan hal tersebut maka diperlukan kajian karakteristik kolam antara lain kajian untuk mengetahui kondisi kualitas air kolam, apakah tercemar atau tidak. Tentunya jika digunakan sebagai sumber air bersih yang memenuhi standar kesehatan sesuai dengan peraturan, maka air tersebut harus diolah terlebih dahulu.

\subsection{Tujuan}

Tujuan kegiatan ini adalah untuk mengetahui status kualitas air yang tertampung dalam kolam bekas tambang batubara di Void Pit Antasena Barat dan Timur.

\section{BAHAN DAN METODE}

\subsection{Lokasi Kegiatan}

Kolam bekas tambang yang dianalisis kualitas airnya adalah void Pit Antasena, tambang Satui, Kabupaten Tanah Laut, Kalimantan Selatan. Void Pit Antasena terbagi menjadi 2 (dua) void, yaitu void Antasena Timur dan void Antasena Barat, dengan luas total 75,4 ha. Void Antasena Timur memiliki luas 46,7 ha dengan prediksi kedalaman void $96 \mathrm{~m}$ dan void Antasena Barat memiliki luas 28,7 ha, prediksi kedalaman $55 \mathrm{~m}$.

\subsection{Bahan dan Peralatan}

Peralatan yang digunakan dalam kegiatan ini antara lain Water quality checker, $\mathrm{pH}$ meter, TDS meter, CTD (Conductivity Temperature Depth), Fish Finder, GPS (Global Positioning System), kamera foto, Flow meter, Water sampler, botol sampel, pelampung dan perahu karet.

\subsection{Metode}

Pengukuran dilakukan secara langsung di lapangan (in situ) serta dengan cara pengambilan sampel air selanjutnya dianalisis di laboratorium. Untuk pengukuran langsung, parameter yang diukur adalah suhu, $\mathrm{pH}, \mathrm{DO}$ (Dissolved Oxygen), TSS (Total Suspended Solid), dan TDS (Total Dissolved Solid).

Sedangkan parameter yang diukur di laboratorium mengacu pada baku mutu peruntukan air sesuai dengan Peraturan Pemerintah No. 82 Tahun $2001^{(7)}$. Sampel air dianalisis di laboratorium Global Banjarmasin.

Lokasi titik sampling kualitas air di Kolam Antasena Timur dan Kolam Antasena Barat (lihat Gambar 1). Pengambilan sampel air di kedua void tersebut diambil pada permukaan dan kedalaman $20 \mathrm{~m}$ dari void seperti terlihat pada Tabel 1.

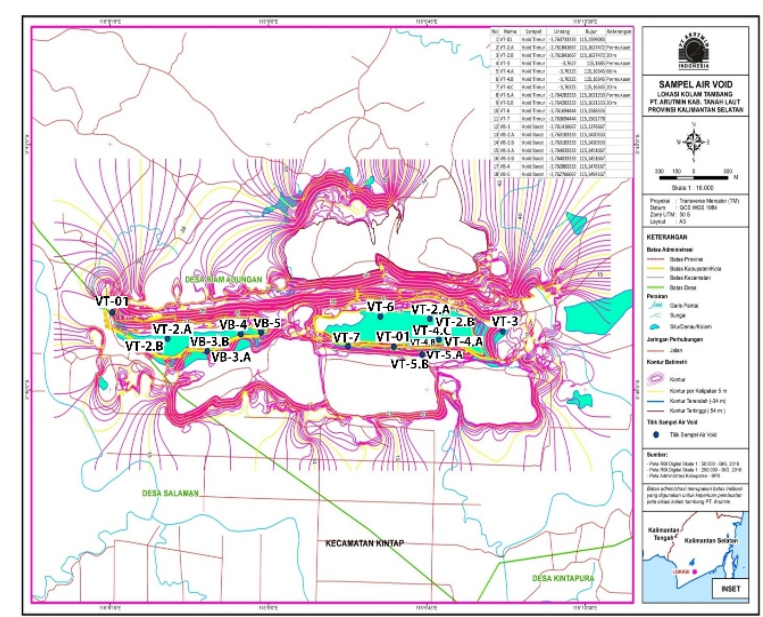

Gambar 1. Titik pengambilan sampel air di kolam pit Antasena

Tabel 1. Kode lokasi pengambilan sample air di void barat dan timur

\begin{tabular}{ll}
\hline \multicolumn{1}{c}{ Void Barat } & \multicolumn{1}{c}{ Void Timur } \\
\hline VB-1 (Permukaan) & VT-01 (Permukaan) \\
\hline VB-2A (Permukaan) & VT-2A (Permukaan) \\
\hline VB-2B (20 m) & VT-2B (20 m) \\
\hline VB-3A (Permukaan) & VT-3 (Permukaan) \\
\hline VB-3B (20 m) & VT-4A (Permukaan) \\
\hline VB-4 (Permukaan) & VT-4B (20 m) \\
\hline VB-5 (Permukaan) & VT-4C (20 m) \\
\hline & VT-5A (Permukaan) \\
\hline & VT-5B (20 m) \\
\hline & VT-6 (Permukaan) \\
\hline
\end{tabular}




\section{HASIL DAN PEMBAHASAN}

Kegiatan pasca tambang batubara menghasilkan void yang tergenang air dan akan menjadi semacam tampungan air hujan dengan volume yang sangat besar. Rencana pemanfaatan kolam tersebut adalah sebagai sumber air, karena dalam Permen ESDM nomor 07 tahun 2014, disebutkan bahwa lahan bekas tambang boleh digunakan untuk keperluan lainnya seperti sumber air, budidaya perikanan, irigasi, dan tempat wisata.

Secara kuantitas volume kedua void sangat besar. Berdasarkan pengolahan data topografi (kontur) dan perhitungan volume maksimal void Antasena dengan bantuan aplikasi ArcGIS 10.2 dengan analisis perhitungan cut and fill tools, diperoleh volume maksimal pada kolam void Timur yaitu sebesar 22.749.574 $\mathrm{m}^{3}$ dan pada void Barat yaitu sebesar $7.847 .751 \mathrm{~m}^{3}$.

\section{Kualitas Air Kolam Antasena Timur dan Kolam Antasena Barat}

\section{Suhu}

Suhu dalam suatu perairan tergantung kepada musim, posisi latitude (letak lintang), altitude (tinggi air permukaan laut), waktu dalam hari, sirkulasi udara, penutupan awan, dan aliran serta stratifikasi kedalaman suatu badan air ${ }^{(8,11)}$. Dampak proses fisika, kimia, dan biologi dalam perairan terjadi karena adanya perubahan suhu(11). Begitupun terjadinya peningkatan viskositas, reaksi kimia, evaporasi, dan volatilisasi akibat peningkatan suhu. Selain itu, penurunan kelarutan gas seperti oksigen, karbon dioksida, nitrogen, dan gas metan akibat peningkatan suhu air dalam air ${ }^{(8,12)}$.

Organisme akuatik memiliki batas toleransi pada rentang suhu tertentu. Peningkatan suhu menyebabkan peningkatan kecepatan metabolisme yang menghasilkan gas hasil respirasi, antara lain gas $\mathrm{CO}_{2}, \mathrm{H}_{2}, \mathrm{CH}_{4}$, dan sebagainya $^{(8)}$. Selain itu, terjadinya peningkatan konsumsi oksigen oleh organisme air disebabkan oleh peningkatan suhu.

Peningkatan konsumsi oksigen oleh organisme akuatik sebesar dua sampai 3 kali lipat akibat meningkatnya suhu perairan sebesar $10{ }^{\circ} \mathrm{C}^{(8,13)}$. Kebutuhan oksigen bagi organisme akuatik untuk melakukan respirasi dan proses metabolisme tidak terpenuhi akibat penurunan kadar oksigen. Pada kondisi rentang suhu tertentu, proses fotosintesis berlangsung melalui mekanisme enzimatis. Proses degradasi enzim dan penghambatan fotosintetis terjadi akibat kenaikan suhu yang terlalu tinggi dalam memacu enzim mengkatalis proses fotosintesis ${ }^{(9,10)}$

Berdasarkan hasil dari pengukuran di lapangan, suhu air di kolam Antasena Timur di permukaan tertinggi $31,3{ }^{\circ} \mathrm{C}$, sedangkan suhu air terendah di dasar kolam $29,7{ }^{\circ} \mathrm{C}$. Suhu air di kolam Antasena Barat tertinggi (permukaan) adalah $30,8^{\circ} \mathrm{C}$, dan suhu air terendah di dasar kolam $28,7^{\circ} \mathrm{C}$. Penurunan suhu secara vertikal dari permukaan sampai ke dasar relatif kecil yakni $1,8{ }^{\circ} \mathrm{C}$ untuk kolam Antasena Timur, sedangkan untuk kolam Antasena Barat penurunan suhu dari permukaan sampai ke dasar kolam 2,1 ${ }^{\circ} \mathrm{C}$. Grafik suhu di Kolam Antasena Timur dan Antasena Barat di tiap titik pengukuran seperti terlihat pada Gambar 2. Kondisi ini menunjukkan bahwa suhu air dari permukaan sampai ke dasar kolam pada kedalaman lebih dari 20 meter mengalami kondisi stratifikasi, tetapi menunjukkan tidak terjadinya termoklin (mengalami perubahan suhu relatif besar) $)^{(8)}$.

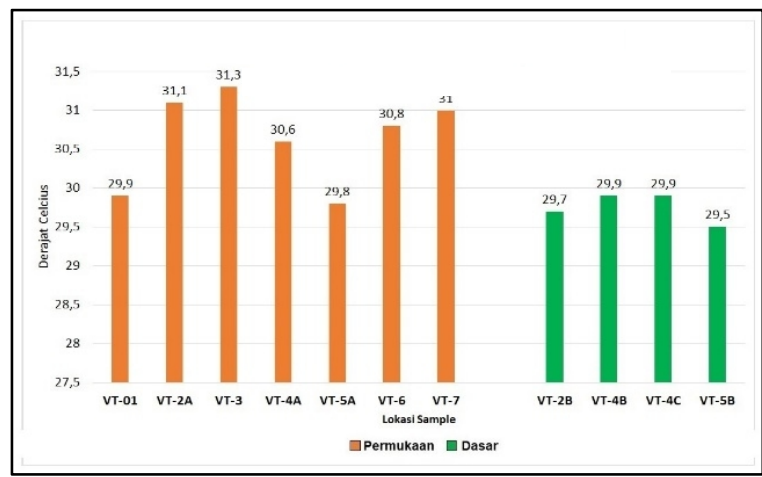

Gambar 2.a Grafik suhu di kolam Antasena Timur

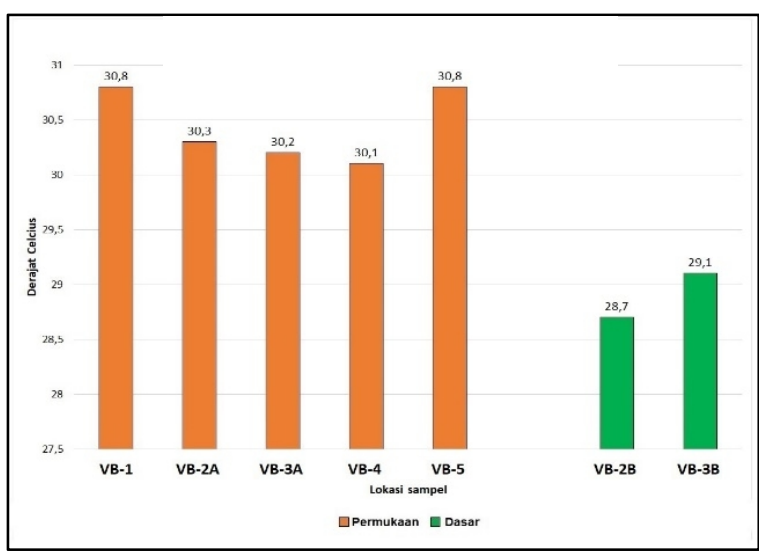

Gambar 2.b Grafik suhu di kolam Antasena Barat

Sehingga, secara keseluruhan suhu air di kedua kolam tersebut masih cukup layak untuk menunjang kehidupan organisme air termasuk ikan ${ }^{(14)}$ dan masih dalam keadaan normal serta masih dalam deviasi 3 atau deviasi temperatur dari keadaan alamiah sesuai dengan baku mutu air klasifikasi kelas satu sampai kelas tiga(15), yaitu air yang peruntukannya untuk dapat digunakan sebagai air baku air minum, untuk prasarana dan sarana rekreasi wisata air, untuk 
pembudidayaan ikan air tawar, air untuk hewan peternakan, dan air untuk irigasi pertanaman, serta peruntukan lainnya dengan memenuhi persyaratan air yang digunakan sama dengan klasifikasi di atas.

\section{TSS (Total Suspended Solid)}

TSS adalah partikel tersuspensi dengan diameter $>1 \mu \mathrm{m}$ yang tertahan pada saringan dengan ukuran diameter pori sebesar 0,45 $\mu \mathrm{m}^{(16)}$. Padatan tersuspensi berupa kumpulan dari lumpur dan pasir halus serta jasad-jasad renik, yang berasal dari kikisan atau erosi tanah yang terbawa ke dalam perairan. Kekeruhan air ditimbulkan oleh masuknya padatan tersuspensi ke dalam perairan.

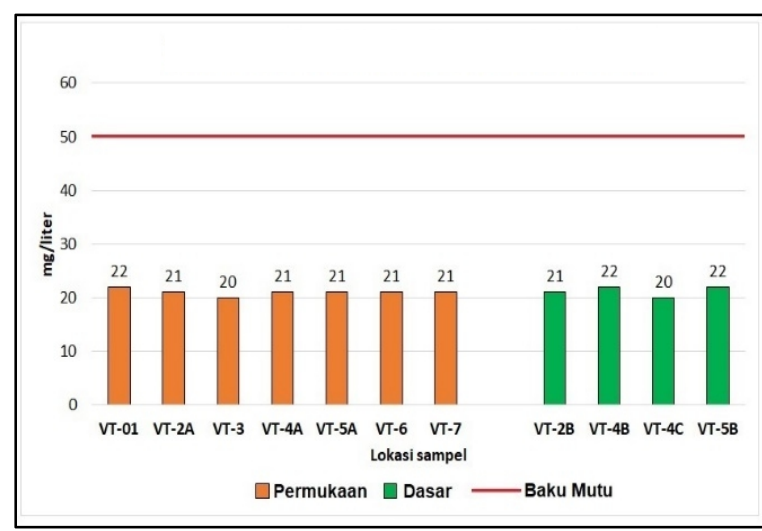

Gambar 3.a Grafik TSS di kolam Antasena Timur

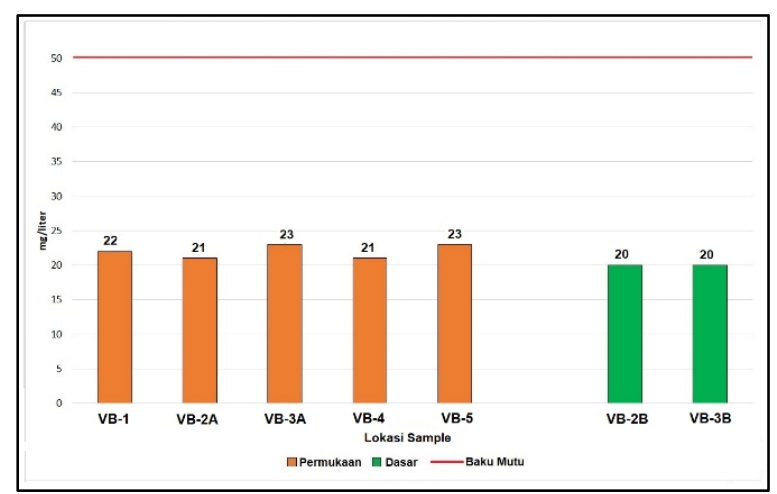

$\square$ Permukaan $\square$ Dasar —Baku Mutu

Gambar 3.b Grafik TSS di kolam Antasena Barat

Hal ini menyebabkan terganggunya keseluruhan dari rantai makanan ${ }^{(17)}$ dalam perairan, karena laju fotosintesis fitoplankton menurun, sehingga berakibat menurunnya produktivitas primer dalam perairan. Terdapat dua macam akibat TSS yang tinggi akan mempengaruhi kondisi biota dalam perairan. Akibat pertama adalah dapat menghambat proses fotosintesis oleh fitoplankton dan tumbuhan air karena TSS yang tinggi menghalangi dan mengurangi penentrasi cahaya ke dalam badan air dan kondisi ini juga mengakibatkan pasokan oksigen terlarut dalam badan air berkurang(19). Selain akibat dari TSS yang tinggi akan mengakibatkan penurunan kedalaman zona fotik atau eufotik, sehingga menurunnya kedalaman perairan produktif $(17,20)$.

Akibat kedua adalah dapat mengganggu secara langsung kehidupan biota perairan, misalnya ikan karena padatan terlarut tersaring oleh insang(18). Berdasarkan hasil pengukuran, konsentrasi TSS di kolam Antasena Timur berkisar antara 20 - 22 mg/liter, sedangkan untuk kolam Antasena Barat TSS berkisar antara 20 - $23 \mathrm{mg} / \mathrm{liter}$. Berdasarkan kelas peruntukan air memenuhi PP No. 82 Tahun 2001(7), kualitas air di Kolam Antasena memenuhi baku mutu peruntukan air kelas I dan kelas 2 yakni dapat digunakan untuk sumber air baku untuk air minum maupun untuk air perikanan.

Dari hasil pengukuran tersebut dapat dilihat bahwa TSS di kolam Antasena Timur sedikit lebih rendah dibandingkan dengan konsentrasi TSS di kolam Antasena Barat. Hal ini dapat diakibatkan tingkat erosi daerah run off di kolam Antasena Barat lebih tinggi(21), sehingga perlu dilakukan langkah-langkah penghijauan dan konservasi tanaman untuk menurunkan laju erosi(22). Grafik konsentrasi TSS di kolam Antasena Timur dan kolam Antasena Barat di tiap titik pengukuran seperti terlihat pada Gambar 3.

\section{TDS (Total Dissolved Solid)}

TDS atau total zat padat terlarut dalam air adalah semua zat terlarut baik anorganik maupun organik yang terkandung dalam air dalam bentuk molekuler, terionisasi atau mikrogranular (koloid sol)(23). TDS biasanya dibahas hanya untuk sistem air tawar.

Penerapan utama studi tentang TDS adalah dalam kualitas air untuk perairan sungai dan danau. Meskipun demikian konsentrasi TDS tidak dianggap sebagai pencemar utama karena tidak dianggap terkait dengan efek kesehatan. Umumnya nilai TDS digunakan sebagai indikasi karakteristik estetika air minum dan sebagai indikator agregat dari timbulnya berbagai macam kontaminan kimia ${ }^{(23)}$.

Sumber utama kehadiran TDS di perairan adalah limpasan pertanian dan permukiman, air pegunungan yang banyak mengandung tanah liat, kontaminasi tanah atau erosi tanah, serta dari air limbah domestik maupun industri. Kalsium, fosfat, nitrat, natrium, kalium, dan klorida merupakan konstituen kimia yang paling umum dijumpai, yang ditemukan dalam limpasan unsur hara (nutrient run off), limpasan air hujan, dan limpasan dari salju(24). 
Bahan-bahan kimia tersebut bisa berupa kation, anion, molekul, atau aglomerasi mikro granula yang dapat larut dalam air. Pestisida yang berasal dari limpasan air permukaan merupakan unsur yang berbahaya dari TDS. Beberapa padatan terlarut alami terbentuk dari pelapukan dan pelarutan batuan dan tanah.

Berdasarkan Permenkes Nomor: 907/Menkes/ SK/VII/2002, konsentrasi TDS di dalam air minum maksimum adalah 1.000 $\mathrm{mg} /$ liter ${ }^{(25)}$, sedangkan berdasarkan SNI Nomor 01-3553-2006 konsentrasi maksimum TDS di dalam air minum adalah $500 \mathrm{mg} / \mathrm{liter}^{(26)}$. Hasil pengukuran secara langsung menunjukkan bahwa konsentrasi TDS di kolam Antasena Timur berkisar 141-155 mg/liter, sedangkan konsentrasi TDS di kolam Antasena Barat berkisar 255-258 mg/l. Berdasarkan pengukuran di laboratorium, konsentrasi TDS di kolam Antasena Timur sekitar 131-155 mg/l, sedangkan konsentrasi TDS di kolam Antasena Barat berkisar 157 - $168 \mathrm{mg} /$ liter.

Berdasarkan hasil pengukuran, konsentrasi TDS di kolam Antasena Barat dan kolam Timur masih memenuhi baku mutu untuk air minum sesuai dengan Permenkes 907/Menkes/SK/VII/ 2002, dan berdasarkan PP Nomor 82 Tahun 2001, masih memenuhi untuk peruntukan air kelas I sampai dengan kelas 3 yakni TDS < $1000 \mathrm{mg} / \mathrm{liter}$ untuk peruntukan air baku air minum, untuk wisata air serta untuk perikanan. Grafik konsentrasi TDS di kolam Antasena Timur dan kolam Antasena Barat di tiap titik pengukuran seperti terlihat pada Gambar 4.

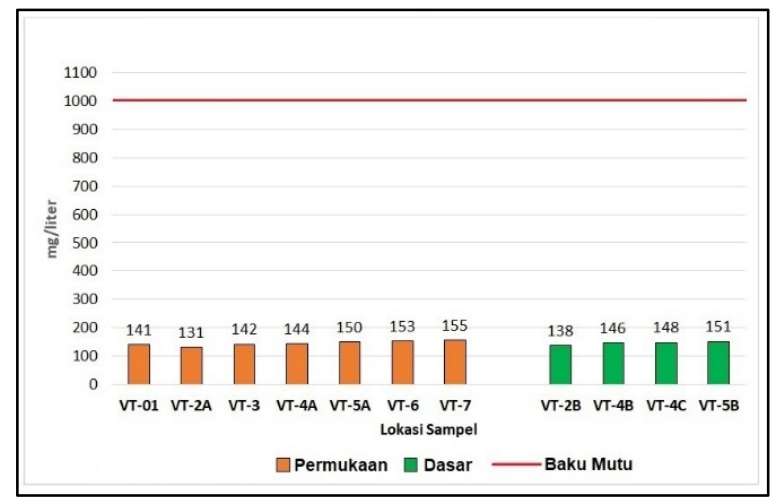

Gambar 4.a Grafik TDS di kolam Antasena Timur

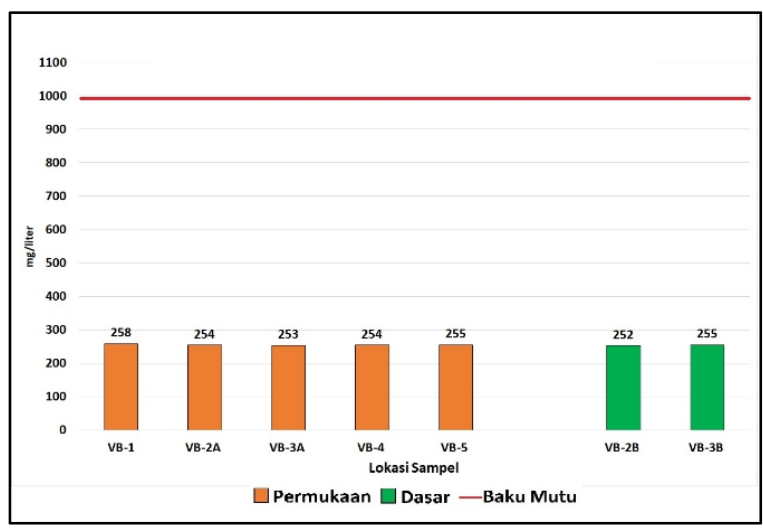

Gambar 4.b Grafik TDS di kolam Antasena Barat

\section{Derajat Keasaman (pH)}

Nilai $\mathrm{pH}$ menunjukkan nilai kadar asam atau basa yang ada dalam larutan, melalui aktivitas ion hidrogen $\left(\mathrm{H}^{+}\right)$yang terlarut. Ketersediaan ion $\mathrm{H}^{+}$selalu dalam keseimbangan dinamis dengan air $\left(\mathrm{H}_{2} \mathrm{O}\right)$ yang membentuk suasana bagi kelang-sungan semua reaksi kimiawi yang berkaitan dengan masalah pencemaran air dan kehidupan makhluk dalam air ${ }^{27)}, \mathrm{pH}$ mempunyai nilai antara $0-14$. Perairan yang memiliki nilai $\mathrm{pH}$ 7 adalah netral, sementara yang memiliki di bawah $\mathrm{pH} 7$ perairan bersifat asam dan $\mathrm{pH}$ di atas 7 perairan bersifat basa. Perairan yang memiliki nilai $\mathrm{pH}$ asam 4 dan $\mathrm{pH}$ basa 11 merupakan titik kematian ikan ${ }^{(28)}$. Pada kondisi produksi ikan yang bagus $\mathrm{pH}$ berkisar $6,5-9$, pada $\mathrm{pH}>9$ merupakan air alkali yang bisa mematikan ikan, sedangkan $\mathrm{pH}<6$ menyebabkan pertumbuhan ikan menjadi lambat. Pada kondisi pH 5 merupakan tingkat keasaman yang mengakibatkan ikan tidak bisa reproduksi ${ }^{(29)}$.

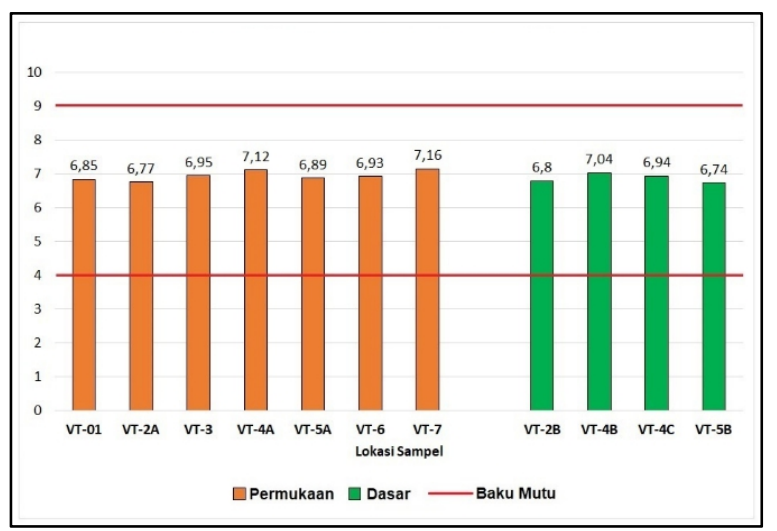

Gambar 5.a Grafik pH di kolam Antasena Timur 


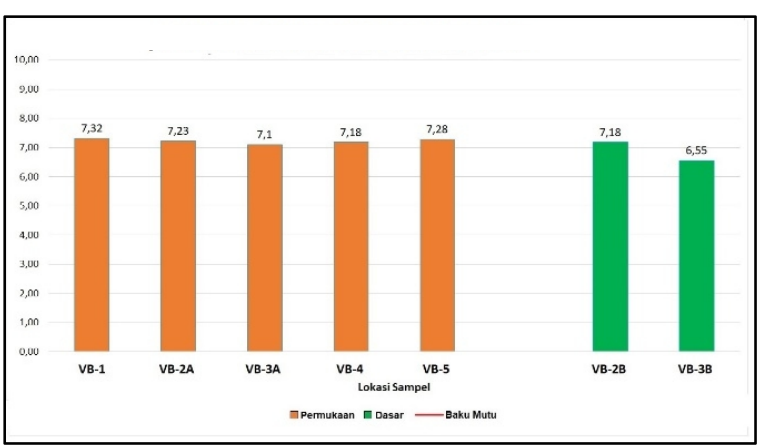

Gambar 5.b Grafik pH di kolam Antasena Barat

Tabel 2. Pengaruh $\mathrm{pH}$ air terhadap pertumbuhan ikan dan crustacea

\begin{tabular}{cl}
$\mathbf{p H}$ & Pengaruh terhadap Ikan dan crustacea \\
\hline 4 & Titik Kematian Asam \\
\hline $4-5$ & Tidak terjadi reproduksi \\
\hline $5-6$ & Pertumbuhan lambat \\
\hline $6-9$ & Pertumbuhan terbaik \\
\hline $9-11$ & Pertumbuhan Lambat \\
\hline 11 & Titik kematian alkali (basa) \\
\hline Sumber : & $\begin{array}{l}\text { Boyd, C.E. (1990) Water quality in ponds for } \\
\text { aquaculture. }\end{array}$
\end{tabular}

Nilai $\mathrm{pH}$ air di kolam Antasena Timur di permukaan kolam berkisar antara 6,86-7,67, sedangkan $\mathrm{pH}$ air dasar kolam berkisar 6,157,67. Nilai $\mathrm{pH}$ air di kolam Antasena Timur di permukaan kolam berkisar antara 7,1-7,32, sedangkan $\mathrm{pH}$ air dasar kolam berkisar 6,557,18. Grafik pH di kolam Antasena Timur dan kolam Antasena Barat di tiap titik pengukuran dapat dilihat pada Gambar 5 di atas.

Secara umum $\mathrm{pH}$ air di kolam Antasena Timur maupun Barat masih dalam kisaran 6-9, sehingga peruntukannya masih sesuai dengan baku mutu air klasifikasi kelas 1 sampai kelas 3 yaitu air yang peruntukannya dapat digunakan sebagai air baku air minum, untuk prasarana dan sarana rekreasi wisata air, untuk pembudidayaan ikan air tawar, air untuk hewan peternakan, dan air untuk irigasi pertanaman, serta peruntukan lainnya dengan mensyaratkan air yang digunakan sama dengan klasifikasi di $\operatorname{atas}^{(7)}$.

$\mathrm{pH}$ air di kolam Antasena di permukaan sampai ke dasar kolam masih dikategorikan normal. Hal ini menunjukkan bahwa reklamasi pasca tambang dalam hal ini penggunaan lapisan penutup menggunakan tanah yang tidak membentuk asam (Non Acid Forming atau NAF) berjalan dengan baik. Selain itu, perairan pada kisaran $\mathrm{pH}$ antara 6-9 merupakan kondisi pertumbuhan ikan yang terbaik seperti terlihat pada Tabel 2.

\section{Oksigen Terlarut (Dissolved Oxygen)}

Makhluk hidup untuk melakukan pernafasan dan metabolisme membutuhkan zat $\mathrm{O}_{2}$ atau oksigen ${ }^{(30)}$. Salah satu parameter yang penting dalam melakukan analisis kualitas air adalah oksigen terlarut (DO) $)^{(31)}$.

Tujuan dilakukannya pengukuran parameter DO adalah untuk mengetahui sejauh mana badan air mampu menampung biota air seperti ikan dan mikroorganisme lainnya. Apabila nilai DO semakin besar pada badan air, ini menandakan badan air tersebut memiliki kualitas air yang bagus. Sebaliknya jika nilai DO semakin rendah, maka badan air tersebut diindikasikan sudah tercemar ${ }^{(31)}$.

Keberadaan oksigen terlarut di perairan sangat dipengaruhi oleh perubahan suhu dan turbulensi serta tekanan atmosfer. Peningkatan suhu, kedalaman dan tekanan atmosfer akan mengurangi kadar oksigen. Munculnya zat pencemar yang dapat mengkonsumsi oksigen menjadi penyebab utama berkurangnya kadar DO atau oksigen terlarut dalam badan air.

Timbulnya limbah organik merupakan sebagian besar dari zat pencemar yang menyebabkan oksigen terlarut berkurang. DO merupakan salah satu komponen utama bagi metabolisme ikan dan organisme lainnya yang dihasilkan dari proses fotosintesa fitoplankton dan makrofita. Kelarutan di dalam air dipengaruhi oleh sifat fisik, kimia, dan biologis perairan. Dengan demikian perubahan pada faktor tersebut di atas berakibat perubahan oksigen terlarut yang pada gilirannya memberikan dampak negatif terhadap organisme air(32).

Jumlah oksigen yang terlarut dalam badan air bergantung pada:

- Tekanan dalam air.

Tekanan gas oksigen terhadap permukaan air semakin besar, maka oksigen yang larut dalam air semakin besar pula (berbanding lurus);

- Suhu air.

Suhu air semakin dingin, maka oksigen yang larut dalam air semakin besar (berbanding terbalik);

- Jumlah mineral dalam air.

Mineral yang terkandung dalam air semakin besar, maka oksigen yang larut dalam air semakin kecil (berbanding terbalik).

Oksigen yang dibutuhkan organisme relatif bervariasi tergantung pada jenis, stadium, dan aktivitasnya. Dalam keadaan normal, kandungan oksigen terlarut minimum adalah 2 ppm dan senyawa beracun atau toksik tidak mencemari. Kehidupan organisme dalam air sudah cukup didukung oleh kandungan oksigen terlarut dengan nilai minimum di $\operatorname{atas}^{(30)}$. 
Pengaruh konsentrasi oksigen terlarut terhadap mahluk hidup di perairan seperti terlihat pada Tabel 2 .

Tabel 2. Pengaruh konsentrasi DO terhadap makhluk hidup ${ }^{(29)}$ di perairan

\begin{tabular}{ll}
\hline $\begin{array}{c}\text { Konsentrasi } \\
\text { oksigen terlarut }\end{array}$ & $\begin{array}{c}\text { Pengaruh terhadap } \\
\text { makhluk hidup di } \\
\text { perairan }\end{array}$ \\
\hline$<1 \mathrm{mg} /$ liter atau & $\begin{array}{l}\text { Jika terjadi lebih dari } \\
\text { beberapa jam, maka } \\
\text { dapat sangat memati- } \\
\text { kan. }\end{array}$ \\
\hline Antara $2-5 \mathrm{mg} /$ liter & $\begin{array}{l}\text { Jika terjadi terus } \\
\text { menerus, maka } \\
\text { pertumbuhan akan } \\
\text { lambat }\end{array}$ \\
\hline Antara $5-8 \mathrm{mg} /$ liter & $\begin{array}{l}\text { Untuk pertumbuhan } \\
\text { yang baik, kondisi ini } \\
\text { adalah terbaik. }\end{array}$ \\
\hline$>8 \mathrm{mg} /$ liter & $\begin{array}{l}\text { Secara normal tidak } \\
\text { ada masalah. }\end{array}$ \\
\hline
\end{tabular}

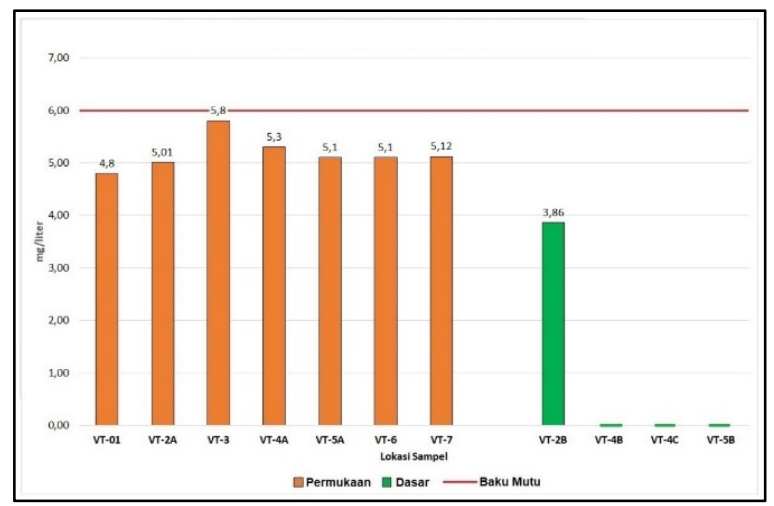

Gambar 6.a Grafik DO di kolam Antasena Timur

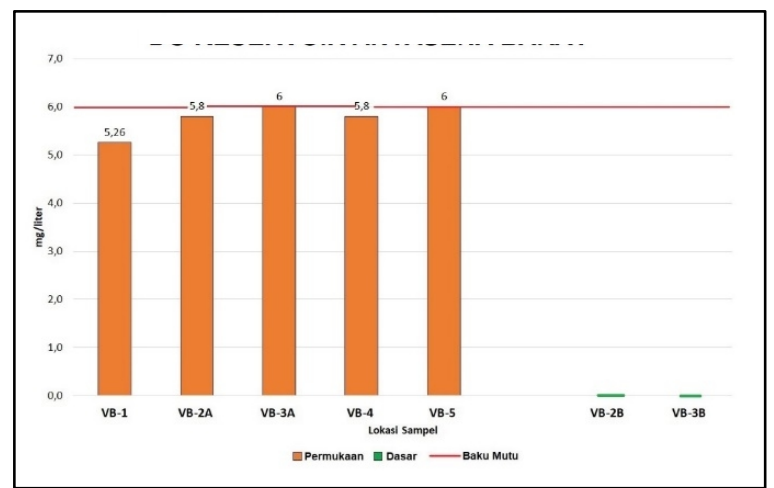

Gambar 6.b Grafik DO di kolam Antasena Barat

Berdasarkan hasil pengukuran, untuk kolam Antasena Timur konsentrasi DO atau oksigen terlarut di permukaan berkisar 4,8-5,8 $\mathrm{mg} / \mathrm{liter}$, sedangkan di bagian dasar $3,86 \mathrm{mg} /$ liter. Untuk kolam Antasena Barat konsentrasi oksigen terlarut di permukaan berkisar 5,26-6 mg/liter.
Penurunan konsentrasi oksigen terlarut terjadi akibat bertambahnya kedalaman, karena semakin berkurangnya proses fotosintesis serta kadar oksigen yang digunakan untuk pernapasan dan oksidasi bahan organik dan anorganik semakin banyak ${ }^{(30)}$.

Secara umum konsentrasi oksigen terlarut di kolam Antasena cukup bagus dan berdasarkan PP Nomor 82 Tahun 2001 sebagian memenuhi peruntukan air kelas I, dan secara keseluruhan memenuhi peruntukan air kelas 2 dan kelas 3 yakni untuk peruntukan perikanan dan wisata air. Grafik konsentrasi oksigen terlarut di kolam Antasena Timur dan Antasena Barat di tiap titik pengukuran seperti terlihat pada Gambar 6.

\section{Zat Organik (BOD, COD)}

Untuk mengetahui banyaknya polutan zat organik di dalam air umumnya dilakukan dengan menggunakan parameter BOD (Biological Oxygen Demand) atau dengan parameter COD (Chemical Oxygen Demand). Mikroorganisme dalam mendekomposisi atau mengurai bahan organik dalam kondisi aerobik membutuhkan sejumlah oksigen terlarut, kondisi ini merupakan karakteristik dari $\mathrm{BOD}^{(33)}$.

COD merupakan jumlah oksigen $\left(\mathrm{mg} \mathrm{O}_{2}\right)$ yang dibutuhkan untuk mengurai seluruh bahan limbah yang terkandung di dalam air(29). Dengan demikian, selisih nilai antara kandungan COD dan BOD menunjukkan besarnya bahan organik yang sulit terurai yang ada dalam perairan. Nilai konsentrasi BOD tidak bisa lebih besar dari nilai $\mathrm{COD}$, tapi mungkin nilai BOD bisa sama dengan nilai COD. Nilai COD menunjukkan jumlah total bahan organik dan umumnya nilai COD selalu lebih besar dari nilai BOD.

Berdasarkan PP No. 82 Tahun 2001(15), peruntukan air kelas 1 yakni untuk pemakaian air baku sebagai air minum, nilai konsentrasi COD maksimum $10 \mathrm{mg} / \mathrm{liter}$ dan BOD $2 \mathrm{mg} / \mathrm{liter}$; peruntukan air kelas 2 yakni air yang dapat digunakan untuk prasarana atau sarana rekreasi wisata air, untuk pembudidayaan ikan air tawar, untuk hewan peternakan, air untuk irigasi pertanaman, dan/atau peruntukan lainnya dengan nilai konsentrasi COD maksimum 25 $\mathrm{mg} / \mathrm{liter}$ dan BOD $3 \mathrm{mg} / \mathrm{liter}$.

Berdasarkan hasil pengukuran kualitas air di kolam Antasena Timur konsentrasi COD berkisar 5,58-6,95 mg/liter, dan BOD 3,5-4,5 $\mathrm{mg} /$ liter. Perbandingan BOD/COD berkisar 0,630,65 . Untuk kolam Antasena Barat, konsentrasi COD 5,72-5,86 mg/liter, dan BOD 3,6-4,2 $\mathrm{mg} /$ liter, perbandingan BOD/COD berkisar 0,630,72 .

Secara keseluruhan konsentrasi COD di kolam Antasena masih lebih kecil dari nilai 10 
mg/liter, sehingga peruntukannya masuk ke peruntukan air kelas 1 yakni untuk sumber air baku untuk air minum, kecuali konsentrasi BOD yakni berkisar 3,0-4,0 mg/liter. Baku mutu BOD untuk air kelas 1 adalah $2 \mathrm{mg} / \mathrm{liter}$. Hal ini tidak ada masalah karena konsentrasi zat organik secara keseluruhan yang ada di dalam air ditunjukkan oleh parameter COD. Parameter BOD menunjukkan jumlah zat organik yang mudah didegradasi secara biologis alami(29).

Perbandingan konsentrasi BOD atau COD secara keseluruhan lebih besar dari 0,6 mg/liter, artinya kandungan zat organik yang ada di dalam air lebih mudah terurai. Grafik konsentrasi COD dan BOD di tiap titik pengukuran seperti terlihat pada Gambar 7 dan 8.

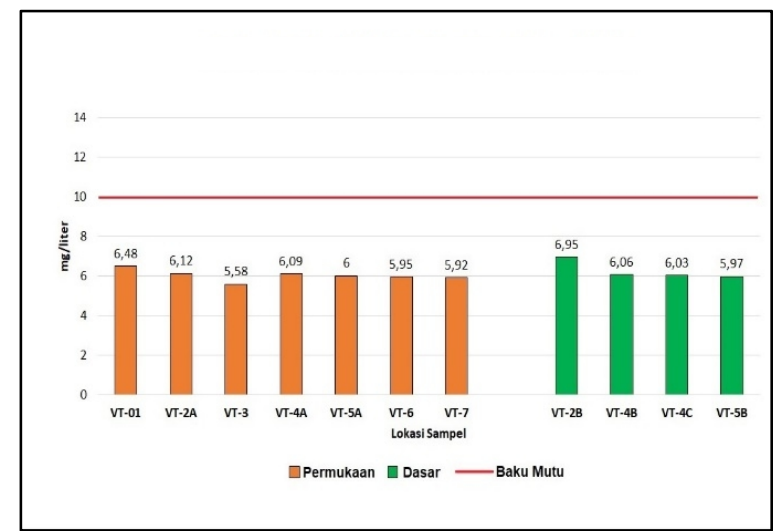

Gambar 7.a Grafik COD di kolam Antasena Timur

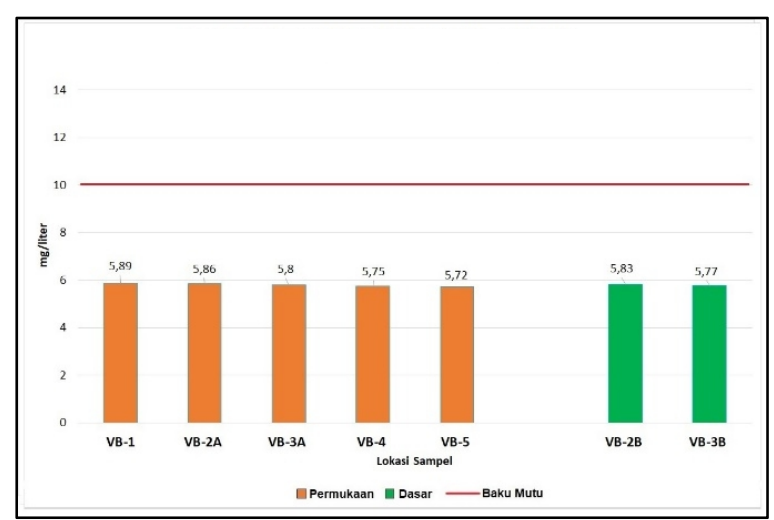

Gambar 7.b Grafik COD di kolam Antasena Barat

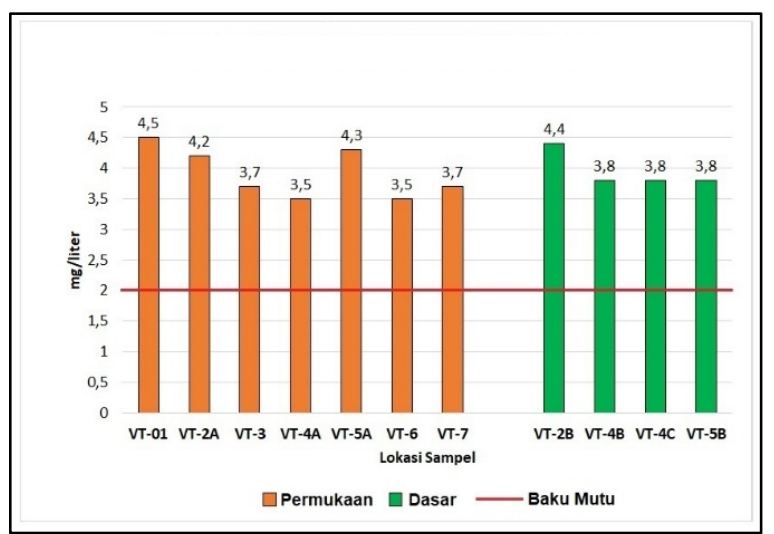

Gambar 8.a Grafik BOD di kolam Antasena Timur

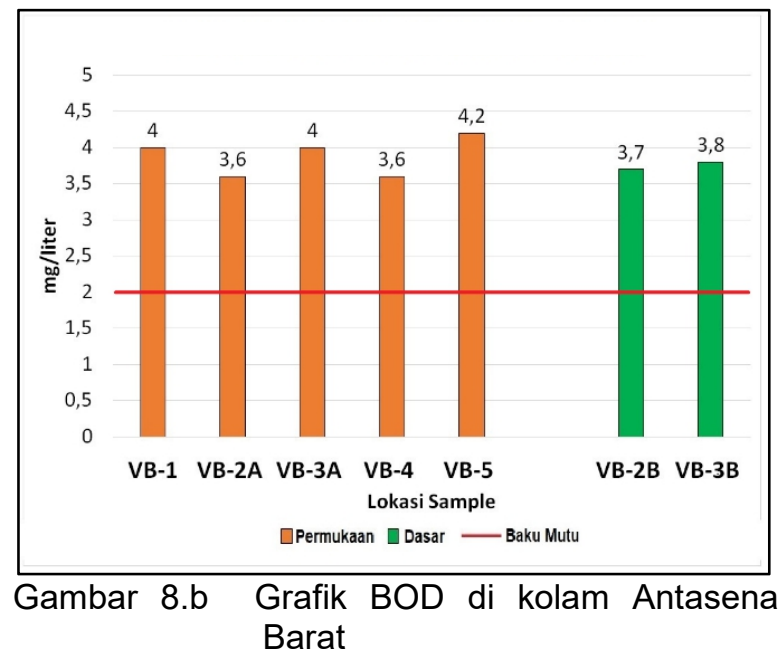

\section{Logam Berat}

Logam berat menurut efek toksikologi, dapat dibagi dalam dua jenis, yaitu logam berat esensial dan logam berat non-essensial atau beracun. Keberadaan logam berat esensial dalam jumlah yang berlebihan akan menjadikan efek racun, sedangkan dalam jumlah tertentu dibutuhkan oleh organisme hidup. Contoh logam berat jenis ini adalah $\mathrm{Zn}, \mathrm{Cu}, \mathrm{Fe}, \mathrm{Co}, \mathrm{Mn}$, dan lain sebagainya. Keberadaan logam berat nonessensial di dalam tubuh dapat bersifat racun dan belum diketahui manfaatnya. Jenis logam berat ini dapat menimbulkan efek negatif bagi kesehatan manusia dan tergantung di bagian mana logam berat ini terikat pada tubuh manusia. Contoh logam berat jenis ini adalah $\mathrm{Hg}, \mathrm{Cd}, \mathrm{Pb}, \mathrm{Cr}$, dan lain-lain ${ }^{(34)}$. Proses metabolisme dalam tubuh akan terputus akibat daya racun akan bekerja sebagai penghalang kerja enzim dalam tubuh. Selain itu jenis logam berat ini dapat menyebabkan alergi, mutagen,dan karsinogen bagi manusia. Logamlogam berat dan senyawa beracun yang banyak di dalam perairan yaitu $\mathrm{Cr}, \mathrm{Ni}, \mathrm{Fe}, \mathrm{Mn}, \mathrm{Zn}, \mathrm{Cu}$, $\mathrm{Cd}, \mathrm{Ag}, \mathrm{Pb}$, dan senyawa sianida.

Dari hasil pemeriksaan sampel air di beberapa lokasi di kolam Antasena Timur dan kolam Antasena Barat terhadap parameter 
logam Arsen (As) $<0,01 \mathrm{mg} / \mathrm{l}$, Cobalt (Co) $<0,02$ $\mathrm{mg} / \mathrm{l}$, Barium (Ba) $<0,277 \mathrm{mg} / \mathrm{l}$, Boron $(\mathrm{B})<0,1$ $\mathrm{mg} / \mathrm{l}$, Selenium (Se) $<0,006 \mathrm{mg} / \mathrm{l}$, Cadmium (Cd) $<0.0004 \mathrm{mg} / \mathrm{l}$, Chrom Hexavalent $\left(\mathrm{Cr}^{6+}\right)<0,001$ $\mathrm{mg} / \mathrm{l}$, Tembaga $(\mathrm{Cu})<0,006 \mathrm{mg} / \mathrm{l}$, Besi $(\mathrm{Fe})$ $0,018 \mathrm{mg} / \mathrm{l}$, Mangan $(\mathrm{Mn})<0,007 \mathrm{mg} / \mathrm{l}$, Timbal $(\mathrm{Pb})<0,0002 \mathrm{mg} / \mathrm{l}$, Zinc $(\mathrm{Zn})<0,004 \mathrm{mg} / \mathrm{l}$ serta Merkuri $(\mathrm{Hg})<0,00009 \mathrm{mg} / \mathrm{l}$, secara keseluruhan konsentrasinya masih memenuhi baku mutu air untuk kelas 1 yakni untuk sumber air baku untuk air minum, dan atau peruntukan lainnya yang mempersyaratkan baku mutu air yang sesuai dengan PP No. 82 Tahun 2001.

\section{Parameter Kualitas Air Lainnya}

Dari hasil rata-rata analisis kualitas air di kolam Antasena Timur dan kolam Antasena Barat untuk parameter lainnya seperti total fosfat $(0,038 \mathrm{mg} / \mathrm{liter})$, nitrat $(0,03 \mathrm{mg} /$ liter $)$, nitrit (0,006 mg/liter), klorida $(5,43 \mathrm{mg} /$ liter $)$, florida $(0,024 \mathrm{mg} / \mathrm{liter})$, sulfat $(0,5 \mathrm{mg} / \mathrm{liter})$, sisa $\mathrm{klor}$ bebas $(<0,01 \mathrm{mg} /$ liter) serta total bakteri $E$. coli $(28 \mathrm{jml} / 100 \mathrm{ml})$ secara keseluruhan memenuhi baku mutu peruntukan air kelas $1^{(7)}$, sehingga peruntukannya secara umum dapat digunakan secara aman untuk semua penggunaan air.

\section{KESIMPULAN}

Berdasarkan hasil analisis kualitas air di kolam Antasena Timur dan Barat diketahui bahwa parameter fisika seperti $\mathrm{pH}$, TDS, dan TSS, kemudian parameter kimia organik seperti $\mathrm{pH}, \mathrm{DO}$, dan COD memenuhi baku mutu kelas 1 (satu). Air tersebut dapat diperuntukkan sebagai sumber air baku untuk air minum. Selain itu parameter-parameter yang termasuk logam berat serta total coliform juga menunjukkan nilai yang memenuhi baku mutu kelas 1 .

Dengan hasil tersebut kualitas air di kolam Antasena tergolong baik dan aman untuk digunakan sebagai air bersih. Jika untuk penggunaan air minum masih perlu dilakukan pengolahan khususnya parameter biologis. Jika untuk air minum, cara sederhana adalah dengan cara merebus sampai mendidih sebelum dikonsumsi.

\section{PERSANTUNAN}

Terima kasih diucapkan kepada pimpinan PT. Arutmin Indonesia beserta jajarannya yang telah memberi kepercayaan kepada kami untuk menjalankan kegiatan ini. Serta terima kasih kepada direktur dan para peneliti Pusat Teknologi Lingkungan (PTL) yang telah mendukung sepenuhnya kegiatan ini.

\section{DAFTAR PUSTAKA}

1. Suseno, T., Haryadi, H. (2013). Analisis Kebijakan Pengendalian Produksi Batubara Nasional dalam Rangka Menjamin Kebutuhan Energi Nasional. Jurnal Teknologi Mineral dan Batubara, 9(1), 23-34.

2. Elisabeth, J., Angaraini, Y. (2017). Pertambangan Batubara. Makalah Jurusan Kimia, FMIPA Universitas Riau.

3. Tiyas, N. (2011). Kajian Pemanfaatan Lubang Bekas Tambang (void) di PT. Adaro Indonesia, Provinsi Kalimantan Selatan. Tesis Program Pasca Sarjana, Studi IImu Lingkungan Universitas Indonesia.

4. Nurisman, E., Cahyadi, R., Hadriansyah, I. (2012). Studi Terhadap Dosis Penggunaan Kapur Tohor $(\mathrm{CaO})$ Pada Proses Pengolahan Air Asam Tambang Pada Kolam Pengendap Lumpur Tambang Air Laya PT. Bukit Asam (Persero), Tbk. Jurnal Teknik Patra Akademika, Edisi 5, Juli 2012, 1-14.

5. Anshariah, Widodo, S., Nuhung, R. (2015). Studi Pengelolaan Air Asam Tambang pada PT. Rimau Energy Mining Kabupaten Barito Timur Provinsi Kalimantan Tengah. Jurnal Geomine, 1(1), 46-54. Jurusan Teknik Pertambangan Fakultas Teknologi Industri, Universitas Muslim Indonesia.

6. Anonim, (2014). PerMen Energi dan Sumber Daya Mineral RI No. 07 Tahun 2014 Tentang Pelaksanaan Reklamasi dan Pasca Tambang pada Kegiatan Usaha Pertambangan Mineral dan Batubara.

7. Anonim, (2001). Peraturan Pemerintah No. 82 Tahun 2001 Tentang Pengelolaan Kualitas Air dan Pengendalian Pencemaran Air.

8. Efendi, H. (2003). Telaah Kualitas Air, Bagi Pengelolaan Sumber Daya dan Lingkungan Perairan. Penerbit Kanisius, Yogyakarta.

9. Falkowski, P.G., Raven, J.A. (1997). Aquatic Photosynthesis. Blackwell Science, Malden, Massachustts, USA.

10.Pitoyo, A., Wiryanto. (2002). Produktifitas Primer Perairan Waduk Cengklik Boyolali. Jurnal Biodiversitas, 3(1), 189-195.

11.Salim, D., Yuliyanto, Baharuddin. (2017). Karakteristik Parameter Oseanografi FisikaKimia Perairan Pulau Kerumputan Kabupaten Kotabaru, Kalimantan Selatan. Jurnal Enggano, 2(2), 218-228.

12. Yulan, A., Anrosan, I.A., Gemaputri, A.A. (2013). Tingkat Kelangsungan Hidup Benih Ikan Nila GIFT (Oreochromis niloticus) Pada 
Salinitas Berbeda. Journal Fisheries Science, XV(2), 78-82.

13.Sugianti, Y., Astuti L.P. (2018). Respon Oksigen Terlarut terhadap Pencemaran dan Pengaruhnya terhadap Keberadaan Sumber Daya Ikan di Sungai Citarum. Jurnal Teknologi Lingkungan, 19(1), 203-211.

14. Samuel, Adiansyah, V. (2016). Kualitas Air, Status Trofik dan Potensi Produksi Ikan Danau Diatas, Sumatera Barat. Jurnal Penelitian Perikanan Indonesia, 22(2), 83-94.

15. Anonim, (2001). Peraturan Pemerintah No. 82 Tahun 2001 Tentang Pengelolaan Kualitas Air dan Pengedalian Pencemaran.

16. Maulana, L., Suprayogi, A., Wijaya, A.P. (2015). Analisis Pengaruh Total Suspended Solid dalam Penentuan Kedalaman Laut Dangkal dengan Metode Algoritma Van Hengel dan Spitzer. Jurnal Geodesi Undip, 4(3), 139-148.

17. Sitorus, M. (2009). Tesis Hubungan Nilai Produkivitas Primer dengan Konsentrasi Klorofil a, dan Faktor Fisik Kimia di Perairan Danau Toba, Balige, Sumatera Utara. Sekolah Pasca Sarjana Universitas Sumatera Utara Medan.

18. Rinawati, R.N., Hidayat, D., Dewi, P.C. (2016). Penentuan Kandungan Zat Padat (Total Dissolve Solid and Total Suspended Solid) di Perairan Teluk Lampung. Jurnal Analytical Environment Chemistry, 1(1), 36-45.

19. Irawan, R., Hendro, R., Ridho, M.R. (2017). Analisis Kualitas Perairan di Sungai Komering Desa Ulak Jermun Kab. Ogan Komering Ilir Sebagai Dasar Pengelolaan Budidaya Ikan Sistem Keramba. Jurnal Akuakultur Rawa Indonesia, 5(2), 182-194.

20. Nybakken, J.W. (1992). Biologi laut: Suatu Pendekatan Ekologis. (Alih bahasa oleh: Muh. Eidman, Koesoebiono, Dietriech G.B., M. Hutomo, S. Sukardjo). Penerbit PT. Gramedia. Jakarta. 459 hal.

21. Ayuningtyas, E.A., Nurlima, A.F., Yudha, R.B. (2018). Pemetaan Erodibilitas Tanah dan Korelasinya terhadap Karakteristik Tanah di DAS Serang, Kulonprogo. Jurnal Nasional Teknologi Terapan, 2(1), 37-46.

22. Lanyala, A.A., Hasanah, U., Ramlan. (2016). Prediksi Laju Erosi pada Penggunaan Lahan Berbeda di Daerah Aliran Sungai (DAS) Kawatuna Propinsi Sulawesi Tengah. EJurnal Agrotekbis, 4, (6), 633-641.
23. Akhter, S. (2013). Performance Assessment of Macrophyte Stabilization Pond-A case Study of Eight Parameters. International Journal of Scientific and Research Publications, 3, (6), 1-6.

24. Ghosh, K.J., da Silva, I. (2018). Application of Geomatics in Civil Engineering: Select Proceeding of ICGCE 2018. Lecture Note in Civil Engineering, page: 317 Springer.

25. Anonim, (2002). KepMenKes RI Nomor 907/Menkes/SK/VII/2002 Tangal 29 Juli 2002 tentang Syarat-syarat dan Pengawasan Kualitas Air Minum.

26. Anonim, (2006). Standar Nasional Indonesia (SNI): Air Minum Dalam Kemasan. Badan Standarisasi Nasional, SNI 01-3553-2006, Hal:2.

27.Alaerts, G., Santika, S.S. (1984). Buku Metode Penelitian Air. Usaha Nasional Surabaya, Indonesia.

28. Andria M.A.F., Rahmaningsih,. (2018). Kajian Faktor Abiotik pada Embung Bekas Galian Tanah Liat PT. Semen Indonesia Tbk. untuk Pemanfaatan Budidaya Ikan dengan Teknologi KJA. Jurnal Ilmiah Perikanan dan Kelautan, 10(2), 95-105.

29. Boyd C.E. (1990). Water Quality in Ponds for Aquaculture. Birmingham Publishing Co. Birmingham, Alabama. p:482.

30.Salmin,. (2005). Oksigen Terlarut (DO) dan Kebutuhan Oksigen Biologi (BOD) Sebagai Salah Satu Indikator Untuk Menentukan Kualitas Perairan. Oseana, XXX(3), 21-26.

31. Kusrini, P., Wiranto, G., Syamsu, I., Hasanah, L. (2016). Sistem Monitoring Online Kualitas Air Akuakultur untuk Tambak Udang Menggunakan Aplikasi Berbasis Android. Jurnal Elektronik dan Telekomunikasi, 16(2), 25-32.

32.Wardoyo, S.T.H. (1982). Water Analysis Manual Tropical Aquatic Biology Program. Biotrop, SEAMEO, Bogor. 81 hal.

33. Hamuna, B., Tanjung, R., Suwito, S., Maury, H., Alianto, A. (2018). Kajian Kualitas Air Laut dan Indeks Pencemaran Berdasarkan FisikaKimia di Perairan Depapre, Jayapura. Jurnal IImu Lingkungan, 16(1), 35-43.

34.Said, N.I. (2010). Metoda Penghilangan Logam Berat (As, Cd, Cr, Ag, Cu, Pb, Ni dan $\mathrm{Zn})$ di Dalam Air Limbah Industri. Jurnal Air Indonesia, 6(2), 136-148. 